\title{
Quality of Life among Elderly People at Geriatric Home
}

\section{Ashgan F. Mohamed*1, Ghada M. Mourad2, Wafaa O. Abd El-Fatah3}

1Clinical Instructors Psychiatric/Mental Health Nursing, Faculty of Nursing Beni Suef University, 2Professor of Psychiatric/Mental Health Nursing, Faculty of Nursing Ain Shams University, and 3 Assistant Professor of Psychiatric/Mental Health Nursing, Faculty of Nursing Helwan University *Corresponding Author.

\section{ABSTRACT}

Background: Aging is a natural process that causes several changes in the physical, psychological, hormonal, and social status. Most of these changes are predicted to affect the quality of life of the elderly. Aim: - is to assess the quality of life among elderly people at geriatric home. Methods: a descriptive research design was performed on a convenient sample consisted of 20 elderlies at Elhlal Elahmer and Noor Wel Amal geriatric homes that are located in Beni-Suef governorate, Egypt. Tools: Data were collected using Socio-demographic Questionnaire, Facts on Aging Quiz, and The Older People's Quality of Life Questionnaire. Results: Study results revealed (70\%) of studied elderlies having a lower quality of life and $(85 \%)$ of them having insufficient knowledge about aging changes. Also, there is a negative significant correlation between sex, source of income and total quality of life, and a positive significant correlation between the levels of education, People who visit regularly, and total QoL. Conclusion: elderlies have a lower quality of life and insufficient knowledge related to aging changes. Recommendations: Develop a psycho-educational program to enhance the quality of life for elderlies at geriatric home, and Provide an in-service training program for nurses who actually working with elderlies about psychological consequences related to aging and scientific base to manage it.

Keywords: Ageing, Quality of Life, Elderlies.

\section{Introduction}

Aging is an essential part of all human life and this unwanted process of becoming older makes it more important. It is the last stage of human life, in this stage, human life becomes weaker from a physical perception as well as more sensitive and emotional from a Psychological perspective. Old age is considered as a curse being related to

Received : 20/5/2020

Accepted : $15 / 6 / 2020$

Online publication : $1 / 10 / 2020$ deterioration of all physical, psychological factors, isolation from social, economic, and other activities (1).

The biopsychosocial changes produced by aging bring about chronic diseases; psychosocial problems and inactivity-related problems, in addition, loneliness may play an etiological role in the growth of physical and mental health problems in older people. Most of these changes are expected to affect the quality of life (QoL) of the elderly (2).

Quality of life of the elderly is defined as how older adults recognize and evaluate 
their lives including lack of depression, perceived health status, and life satisfaction with domains such as health status, financial situation, relationship with their spouse and children, and sexual activity through participating in leisure activities. QoL in old age is a great extent determined by conditions, events, and decisions during childhood and adulthood including by environment and lifestyle factors (3).

Moreover, aging is one of the unavoidable life stages and cannot be prevented, but elderlies who have a thorough understanding of the challenges they are facing as well as knowledge related to aging changes are often better able to address difficulties, identify of personal coping ability, internal and external resources, their areas of strength, and as a result they feel more in control of the condition(s), and have a better quality of life (4).

\section{Significance of the Study}

Worldwide, the average life span of people has been increasing., several reasons including heredity, lifestyle, and a healthy diet, avoiding smoking, and physical activity can affect the longevity of life (5).

In Egypt, One of the main features of the Egyptian population over the last few decades is the ongoing increase in the absolute and relative numbers of older people. In 2050, Egypt is predictable to have the largest number of old (23.7 million) and oldest-old (3.1 million) populations in the area. If this trend continues we will, hereafter, have a population which is known as the elderly population (6).

Moreover, aging is a lifelong process of growing up and growing old and is considered as a curse being associated with worsening of all physical, psychological, social, economic, and other activities. Most of these changes are expected to affect the quality of life of the elderly, so it is important to assess the quality of life and knowledge related to aging changes for the elderly.

Aim of the Study: assess the quality of life among elderly people at geriatric homes.

\section{Research Question:}

1) What is the quality of life for the elderly at geriatric home?

2) Do elderlies have sufficient knowledge related to aging changes?

\section{Subjects and Methods}

Research Design: A descriptive research design was selected to fulfill the aim of the study and answer the research questions. 
The setting of the Study:

This study conducted at Elhlal Elahmer and Noor Wel Amal geriatrics home that is located in Beni-Suef governorate, Egypt.

\section{Type of Sample:}

A convenient sample was selected in the current study. All elderlies enrolled in both Elhlal Elahmer geriatric home and Noor Wel Amal geriatric home that have a satisfactory level of cooperation and free from psychiatric disorders were included in the study after obtaining informed consent for participation

\section{Data Collections Tools}

Data were collected using the following:

\section{Socio-Demographic Questionnaire:}

It was developed by the researcher after reviewing related literature. It includes 15 self-reported items which include items such as age, gender, education level, place of residence, marital status, occupation, economic status....... etc and medical history of the elderly.

\section{2-Facts on Aging Quiz (Breytspraak \&} Badura, 2015):

The Facts on Aging Quiz adapted from (7) was used to measure knowledge about aging. The original quiz consists of 50 items, certain modifications were done by the research investigator in the adapted quiz such as excluded (21) items and added extra (3) items to the original quiz to suit the studied subjects and nature of the study. This tool consisted of 32 items comprising physical (12 items), psychological (10 items), mental (5 items), and social (5 items) subcategories. Responses based on aging change were scored 1 , and responses that not based on aging change were scored 0 . The total score ranged from 0 to 32 , with a higher score indicating a higher level of correct knowledge about aging.

\section{3- The Older People's Quality of Life Questionnaire (OPQOL):}

The Older People's Quality of Life Questionnaire (OPQOL) adapted from (8) was used for assessment of the quality of life for the elderly. This tool consisted of 40 statements that cover the following dimensions life overall (4 items), health ( 8 items), social relationships and participation (6 items), independence, control over life and freedom (3 items), home and neighborhood (4 items), psychological and emotional well-being (9 items), leisure and activities (4 items), culture and religion (2 items).

The participant is asked to indicate the extent to which he/she agrees with each statement by selecting one of five possible options ("strongly disagree", " disagree", "neither agree nor disagree", "agree" and 
"strongly agree", each with a score of (1-5). Higher scores indicate a higher QOL. The total score ranges from 40 (worst possible QOL) to 200 (best possible QOL).

\section{Pilot Study}

The pilot study was conducted on $10 \%$ of the total study sample to ensure the clarity of questions, the applicability of the tools, and the time needed to complete them. The necessary modifications were done as a result of the pilot study; pilot study subjects were excluded from the actual study sample.

\section{Ethical Consideration}

The ethical research considerations in this study included the following:

1. Written initial approval was obtained from the research ethical committee at the Faculty of Nursing, Helwan University.

2. Individual oral consent was obtained from each participating subject after explaining the nature and benefits of the study.

3. The researcher cleared the objectives and aim of the study to participating students.

4. The researcher maintained the anonymity and confidentiality of participating elderlies.
5. Participating elderlies were allowed to choose to participate or not in the study, and were given the right to withdraw at any time from the study.

\section{Results}

Table (1a): Socio-demographic Characteristics among Studied subjects. $(n=20)$

\begin{tabular}{|c|c|c|}
\hline Item & No & $\%$ \\
\hline \multicolumn{3}{|l|}{ Age in years } \\
\hline - Less than70 & 14 & 70 \\
\hline - $71-80$ & 3 & 15 \\
\hline $\begin{array}{l}\text { - } \quad \text { More than } \\
80\end{array}$ & 3 & 15 \\
\hline \multicolumn{3}{|c|}{ Mean \pm SD $69.65 \pm 7.81$ year } \\
\hline \multicolumn{3}{|l|}{ Sex } \\
\hline - $\quad$ Male & 11 & 55 \\
\hline - $\quad$ Female & 9 & 45 \\
\hline \multicolumn{3}{|l|}{ Marital status } \\
\hline - $\quad$ Single & 5 & 25 \\
\hline - $\quad$ Divorce & 1 & 5 \\
\hline - $\quad$ widow & 8 & 40 \\
\hline - $\quad$ Married & 6 & 30 \\
\hline \multicolumn{3}{|c|}{ Occupation before retirement } \\
\hline $\begin{array}{l}\text { Governmental } \\
\text { Working }\end{array}$ & 8 & 40 \\
\hline Free Business & 6 & 30 \\
\hline Not working & 6 & 30 \\
\hline \multicolumn{3}{|l|}{ Level of Education } \\
\hline Illiterate & 5 & 25 \\
\hline Reading and writing & 6 & 30 \\
\hline Secondary & 6 & 30 \\
\hline Academic & 2 & 10 \\
\hline Postgraduate & 1 & 5 \\
\hline
\end{tabular}

Table (1a) reveals that $70 \%$ of studied subjects aged less than 70 years with mean age $(69.65 \pm 7.81)$, while $55 \%$ of studied subjects were males and $40 \%$ of them were 
widows. In addition, $40 \%$ of the studied subjects reported that they had governmental working. Regarding education, the most reported education level among studied subjects is reading and writing and secondary education $30 \%$, followed by $25 \%$ being illiterate.

\begin{tabular}{|c|c|c|}
\hline \multicolumn{3}{|c|}{$\begin{array}{l}\text { Table (1b): Socio-demographic } \\
\text { Characteristics of Studied Subjects } \\
(\mathbf{n = 2 0 )} .\end{array}$} \\
\hline Item & No & $\%$ \\
\hline \multicolumn{3}{|c|}{ Is your monthly income sufficient } \\
\hline$\bullet \quad$ Yes & 15 & 75 \\
\hline$\bullet \quad$ No & 5 & 25 \\
\hline \multicolumn{3}{|l|}{ Source of income } \\
\hline • My sons & 1 & 5 \\
\hline - $\quad$ Relatives & 6 & 30 \\
\hline - $\quad$ Pension & 13 & 65 \\
\hline - A charity & 1 & 5 \\
\hline \multicolumn{3}{|c|}{ People who visiting you regularly } \\
\hline • My sons & 8 & 40 \\
\hline - $\quad$ My relatives & 8 & 40 \\
\hline - $\quad$ My neighbors & 1 & 5 \\
\hline - $\quad$ None & 3 & 15 \\
\hline \multicolumn{3}{|c|}{$\begin{array}{l}\text { The reason for joining the geriatric } \\
\text { home }\end{array}$} \\
\hline $\begin{array}{l}\text { There is no one caring for } \\
\text { me }\end{array}$ & 12 & 60 \\
\hline $\begin{array}{l}\text { Stay away from family } \\
\text { problems }\end{array}$ & 1 & 5 \\
\hline feeling lonely & 5 & 25 \\
\hline $\begin{array}{l}\text { leave the apartment for one } \\
\text { of my sons to marry where }\end{array}$ & 2 & 10 \\
\hline \multicolumn{3}{|c|}{ Duration of stay in a geriatric home } \\
\hline Less than one year & 3 & 15 \\
\hline from one to five years & 13 & 65 \\
\hline From 5 to 10 years & 1 & 5 \\
\hline More than 10 years & 3 & 15 \\
\hline
\end{tabular}

Do you live in a shared room

\begin{tabular}{|c|c|c|}
\hline$\bullet \quad$ Yes & 12 & 60 \\
\hline$\bullet \quad$ No & 8 & 40 \\
\hline
\end{tabular}

Table (1b) shows that the source of income for $65 \%$ of studied subjects depend on pension, while $60 \%$ of studied subjects staying in a geriatric home from one to five years, and $60 \%$ of them live in a shared room. Regarding the reason for joining the geriatric home, $60 \%$ of studied subjects say that there is no one caring for me.

\begin{tabular}{|c|c|c|}
\hline \multicolumn{3}{|c|}{ 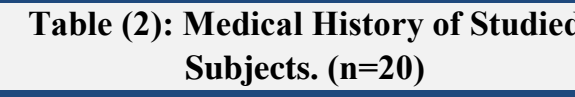 } \\
\hline Item & No & $\%$ \\
\hline \multicolumn{3}{|c|}{ Past history of chronic disease* } \\
\hline HTN & 9 & 45 \\
\hline $\mathrm{DM}$ & 4 & 20 \\
\hline Renal disease & 3 & 15 \\
\hline $\begin{array}{l}\text { Cardiac and vascular } \\
\text { disease }\end{array}$ & 3 & 15 \\
\hline Respiratory disease & 1 & 5 \\
\hline $\begin{array}{l}\text { Arthritis and Orthopedic } \\
\text { disease }\end{array}$ & 3 & 15 \\
\hline \multicolumn{3}{|l|}{ Period of chronic disease } \\
\hline Less than one year & 0 & 0 \\
\hline From 1 to 5 years & 11 & 55 \\
\hline More than five years & 9 & 45 \\
\hline
\end{tabular}

*Numbers aren't mutually exclusive

Table (2) reveals that $45 \%$ of studied subjects having hypertension, and $20 \%$ of them having diabetes. Regarding the Period of chronic disease $55 \%$ of studied subjects having chronic diseases from one year to five years. 
Figure (1): Total Knowledge of Aging Changes as Reported by Studied Subjects. $(\mathbf{n}=\mathbf{2 0})$

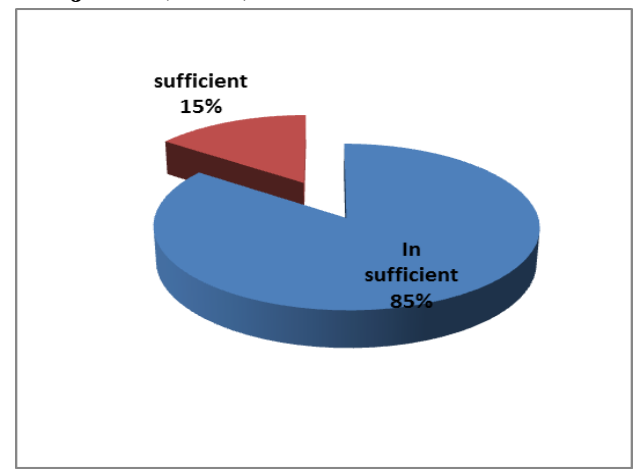

Figure (1) clarifies $85 \%$ of studied subjects have insufficient knowledge and $15 \%$ of them have sufficient knowledge related to aging changes.

Figure (2): Total Quality of Life as Reported by Studied Subjects. $(n=20)$

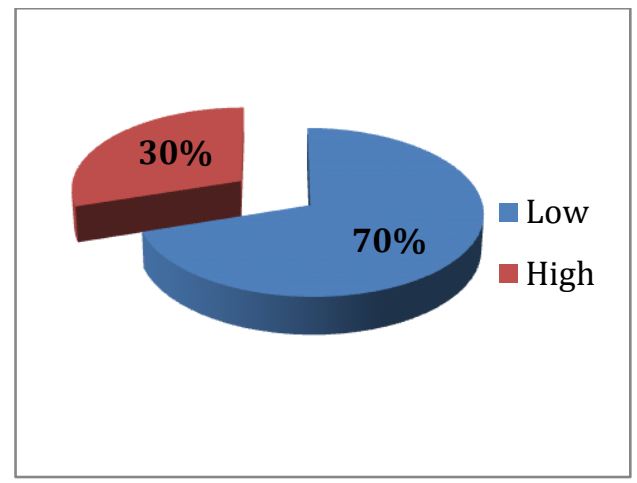

Figure (1) clarifies $70 \%$ of studied subjects have a lower quality of life and $30 \%$ of them have a higher quality of life.
Table (3): Correlation between Sociodemographic Characteristics, Medical History, and Total knowledge about aging change as reported by Studied Subjects. $(n=20)$

\begin{tabular}{|c|c|c|}
\hline \multirow{2}{*}{$\begin{array}{l}\text { Socio-demographic } \\
\text { Characteristics }\end{array}$} & \multicolumn{2}{|c|}{ Total knowledge } \\
\hline & $r$ & P-value \\
\hline Age in years & 0.425 & .062 \\
\hline Sex & -0.644 & $.049 *$ \\
\hline Marital status & 0.124 & .603 \\
\hline Job & $-0.242-$ & .305 \\
\hline Level of Education & 0.633 & $.047 *$ \\
\hline Residence: & 0.080 & .736 \\
\hline $\begin{array}{l}\text { Is your monthly } \\
\text { income sufficient }\end{array}$ & -0.137 & .564 \\
\hline Source of income & -0.137 & $.038 *$ \\
\hline $\begin{array}{l}\text { People who visiting } \\
\text { you regularly }\end{array}$ & -0.039 & .87 \\
\hline $\begin{array}{l}\text { The reason for joining } \\
\text { the geriatric home }\end{array}$ & $-0.092-$ & .699 \\
\hline $\begin{array}{l}\text { Duration of stay in a } \\
\text { geriatric home }\end{array}$ & 0.055 & .819 \\
\hline $\begin{array}{l}\text { Do you live in a } \\
\text { common room }\end{array}$ & 0.065 & .802 \\
\hline $\begin{array}{l}\text { Past history of chronic } \\
\text { disease }\end{array}$ & 0.244 & .300 \\
\hline $\begin{array}{lll}\begin{array}{l}\text { Period of } \\
\text { disease }\end{array} & \text { chronic } \\
\end{array}$ & 0.148 & .533 \\
\hline
\end{tabular}

* Significant at $\mathrm{p}<0.05{ }^{* *}$ highly significant at $\mathrm{p}<0.01 \quad \mathrm{r}=$ Pearson correlation

Table (3) reveals that there is a negative significant correlation between sex and total knowledge, and a positive significant correlation between the level of education, source of income and total knowledge related to aging change. 
Table (4): Correlation between Sociodemographic Characteristics, Medical History, and Quality of Life as reported by Studied Subjects. $(n=20)$

\begin{tabular}{|l|l|l|}
\hline \multirow{2}{*}{$\begin{array}{l}\text { Socio-demographic } \\
\text { Characteristics }\end{array}$} & \multicolumn{2}{|l|}{ Total QoL } \\
\cline { 2 - 3 } & $\boldsymbol{r}$ & P-value \\
\hline Age in years & 0.161 & .497 \\
\hline Sex & -0.482 & $.031^{*}$ \\
\hline Marital status & -0.144 & .545 \\
\hline Job & 0.187 & .429 \\
\hline Level of Education & 0.516 & $.041^{*}$ \\
\hline Residence: & -0.285 & .223 \\
\hline $\begin{array}{l}\text { Is your monthly } \\
\text { income sufficient }\end{array}$ & -0.027 & .911 \\
\hline Source of income & -0.502 & $.023^{*}$ \\
\hline $\begin{array}{l}\text { People who visiting } \\
\text { you regularly }\end{array}$ & 0.540 & $.042^{*}$ \\
\hline $\begin{array}{l}\text { The reason for joining } \\
\text { the geriatric home }\end{array}$ & -0.123 & .506 \\
\hline $\begin{array}{l}\text { Duration of stay in a } \\
\text { geriatric home }\end{array}$ & 0.308 & .186 \\
\hline $\begin{array}{l}\text { Do you live in a } \\
\text { common room }\end{array}$ & 0.233 & .323 \\
\hline $\begin{array}{l}\text { Past history of } \\
\text { chronic disease }\end{array}$ & -0.420 & .065 \\
\hline $\begin{array}{l}\text { Period of chronic } \\
\text { disease }\end{array}$ & 0.193 & .414 \\
\hline
\end{tabular}

* Significant at $\mathrm{p}<0.05 * *$ highly significant at $\mathrm{p}<0.01$ $\mathrm{r}=$ Pearson correlation

Table (4) reveals that there is a negative significant correlation between sex, Source of income and total QoL, and a positive significant correlation between the levels of education, People who visit regularly, and total QoL.
Table (5): Relation between Total knowledge and Total Quality of Life as reported by Studied Subjects. $(n=20)$

\begin{tabular}{|l|c|c|}
\hline \multirow{2}{*}{ Items } & \multicolumn{2}{|c|}{ Total knowledge } \\
\cline { 2 - 3 } & $\mathbf{X 2}$ & P-value \\
\hline $\begin{array}{l}\text { Quality } \\
\text { of Life }\end{array}$ & $\mathbf{6 0 . 0 0 0}$ & $0.000^{* *}$ \\
\hline
\end{tabular}

** Highly significant at $\mathrm{p}<0.01$

In this table by analyzing the relation between total quality of life and total knowledge of studied subjects, there is a highly significant relationship between total quality of life and total knowledge $(\mathrm{p}<0.01)$.

\section{Discussion}

Aging is unavoidable developmental facts that bring along several changes in the physical, psychological, hormonal, and social status. Most of these changes are predictable to affect the QoL of the elderly. One of the greatest challenges to public health is to improve the quality of later years of life as life expectancy continues to rise (9).

The present study was carried out on twenty elderlies who lived in the geriatric home, the current study results revealed that more than two-thirds of studied elderlies aged less than seventy years old with a mean age $(69.65 \pm 7.81)$ years. This result 
consistent with the study of ĆwirlejSozańska1, Sozański (10) who declared that the mean age of studied subjects was 69.6 \pm 6.1 years.

Regarding marital status, more than two-fifth of studied elderlies were widows this result may be due to one of the causes for joining a geriatric home is that husband or wife dead and there is no one for caring. This result comes in agreement with a study done by Shokry, Adel (11) who showed that less than one-third of studied elderlies were a widow.

Concerning the educational level, the present study result clarified that slightly less than one-third of studied elderlies were secondary level also one-third of them were reading and writing. This result may be due to in the past most of the people not reaching to high education level and they satisfied with they be able to writing and reading and secondary level and also, in this time the educator did not get the attention to develop themselves, also the stress of education. This results consistent with (12) who reported that slightly more than a third of studied elderlies were reading and writing and one-quarter of them were secondary level

Regarding monthly income, threequarters of studied elderlies satisfied with their monthly income and they saw that is sufficient for them. This result may be due to the elderlies were staying in the geriatric home and the administration of geriatric home is reasonable for everything related to them. This result consistent with (13) who reported that slightly more than half of the studied elderlies were financially independent.

Regarding the Source of income, twothirds of studied elderlies depend on Pension as a source of income. This result may be due to According to Egyptian laws, anyone who works and exceeds 60 years of age and retires, he will receive a pension. If he does not work, he will receive a pension at 65 years of age. This result disagrees with (14) who reported that slightly less than one-quarter of studied elderlies depend on Pension as a source of income. This contradiction may be due to different studied samples, settings, and cultures.

Concerning the reason for joining the geriatric home, the present study shows that slightly less than two-thirds of studied elderlies said that there is no one caring for them. This may be due to life's stressors related to (family, work, financial ......et) and no one in the family caring for the elderly and they have the feeling of ignorance and lack of emotional support. This finding disagrees with (15) who reported that slightly less than one-third of 
studied elderlies joined the geriatric home due to poverty and misbehavior of sons and daughters. This contradiction may be due to different settings and cultures.

Regarding the history of chronic disease, the present study clarified that, slightly less than half of the studied elderlies having hypertension and a fifth of them having diabetes mellitus. These results may be due to physiological aging changes and genetic factors. These results agree with (16) who reported that less than half of studied elderlies having hypertension and less than one-quarter of studied elderlies having diabetes mellitus.

Concerning the knowledge related to aging changes, the present study result clarified that most of the studied elderlies had insufficient knowledge about aging changes. This finding indicates that older adults have misconceptions about aging. This results consistent with (17) who reported that studied elderlies had a lower level of knowledge about aging changes.

Concerning the quality of life for elderlies, the present study clarified that two-thirds of the studied elderlies having a lower quality of life. These results may be due to staying at a geriatric home away from their families and friends, aging changes, and chronic disease. These results agree with (9) who reported that elderly who living in geriatric homes experience a lower quality of life than elderlies who live with their families.

Regarding the correlation between socio-demographic characteristics and total QoL, participating elderlies showed a negative significant correlation between sex and total QoL. This relationship describing that the QOL was significantly better in the male sex. This can be attributed to female tendency to consider their health worse compared to men of the same age, less personal relationship with their colleagues, and hormonal change; all these can affect negatively on females QoL. In agreement with the current study results, the study of (13) who reported that QOL was significantly better among the male elderly.

Concerning the correlation between the level of education and total QoL, participating elderlies showed a positive significant correlation between the level of education and total QoL. This relationship describing that QOL was significantly better in higher educated elderly. This can be correlated to the level of education confers several advantages for health, such as influences of psychosocial factors and behavior. Individuals with a higher educational level are less likely to be 
exposed to risk factors for diseases and to be submitted to inadequate working conditions. In addition, higher educational level promotes access to information, the modification of lifestyle to adopt healthy habits, the demand for health services to engage in activities that prioritize health promotion, and especially to follow correct guidelines related to achieving a better QoL.

In agreement with the current study result, the study of (18) who investigated educational level, socio-economic status, and relationship with QoL in elderly residents of the city of Porto Alegre/RS, Brazil. They revealed that there was a positive significant correlation between the level of education and total QoL.

Concerning the correlation between People's visiting at geriatric home and total QoL, participating elderlies showed a positive significant correlation between people's visiting and total QoL. This relationship describing that elderlies who had peoples visiting him regularly reported better QOL. This can be attributed to the deterioration of health in old age requires more participation, family support, and more social contacts that act as protectors of health. Contacts are influenced not only by how long they last but also by their influence or importance. It is not important to have contact with many different people, but it is important to have contact with those who provide a sense of comfort, who was chosen by the older person and who last long enough to be able to interact, talk, and share common topics of conversation

In agreement with the current study result, the study of (19) who revealed that there was a positive significant correlation between People's visiting and total QoL.

Regarding the correlation between knowledge about aging changes and total QoL, the present study result illustrated that there was a positive significant correlation between total knowledge and total QoL. This relationship describing that elderlies who had sufficient knowledge reported higher QOL. This can be related to aging is one of the inevitable life stages and cannot be prevented, but it can be postponed or its problems can be decreased through focusing on a healthy lifestyle to transform it into an enjoyable stage. So, when the knowledge of the elderly on their physical, mental, social, and nutritional needs increases, they can adapt themselves to the aging better.

In agreement with the current study result, the study of (20) who revealed that there was a positive significant correlation between knowledge about aging changes and QoL. In addition, the study of (17) 
supported the current study results, the researchers revealed that better knowledge about aging was associated with enhanced life satisfaction. So, it is important for the psychiatric nurse to increase and improve knowledge related to aging changes for elderlies to adapt themselves to the aging better.

\section{Conclusion}

Based on the findings of the current study, it was concluded that elderlies at geriatric homes have a lower quality of life and insufficient knowledge related to aging changes. In addition, there is a negative significant correlation between sex, Source of income and total QoL, and a positive significant correlation between the levels of education, People who visit regularly, and total QoL.

\section{Recommendations}

The recommendations will be illustrated as follow:

1) Develop a psycho-educational program to enhance the quality of life for elderlies at geriatric home.

2) Educational programs that include all psychological consequences related to aging and how to manage it should be added to the nursing curriculum of geriatric nursing.

3) Provide an in-service training program for nurses who actually working with elderlies about psychological consequences related to aging and scientific base to manage it.

4) Replication of the study using a large study sample in different settings to generalized the results..

\section{Conflict of Interest}

The authors declared no potential conflicts of interest with respect to the research, authorship, and/or publication of this article.

\section{References}

1. Panday R, Kumar P. Quality of life among elderly living in old age home: a brief overview. Delhi psychiatry journal. 2017;20(2).

2. Bakar N, Așılar R. Factors affecting depression and quality of life in the elderly. J Gerontol Geriatr Res. 2015;4(249):2.

\section{Cole S, McCormick C,} Jennifer A, Huber L. Leisure behavior and quality of life in older korean adults. ProQuest LLC: Graduate Faculty, Indiana University,; 2015.

4. Groenewald E, Joska J, Araya R. Psychotherapy adaptation in aging populations. Global Mental Health and Psychotherapy: Elsevier; 2019. p. 321-40. 
5. World Health Organization. World report on ageing and health: World Health Organization; 2015.

6. Sweed H. Egypt Report. Middle East Journal of Age and Ageing. 2016;13(2).

7. Breytspraak L, Badura L. Facts on Aging Quiz (revised; based on Palmore (1977; 1981)). 2015.

8. Bowling A, Hankins $M$, Windle G, Bilotta C, Grant R. A short measure of quality of life in older age: The performance of the brief Older People's Quality of Life questionnaire (OPQOL-brief). Archives of gerontology and geriatrics. 2013;56(1):181-7.

9. Shrestha M, Heera K, Bhattarai P, Mishra A, Parajuli SB. Quality of life of elderly people living with family and in old age home in Morang District, Nepal. BIBECHANA. 2019;16:221-7.

\section{0. Ćwirlej-Sozańska1 AB,} Sozański B, Wiśniowska-Szurlej A, Wilmowska-Pietruszyńska A. Quality of life and related factors among older people living in rural areas in south-eastern

Poland. Annals of Agricultural and Environmental

Medicine. 2018;25(3).
11. Shokry AAE, Adel MR, Rashad AE-sA. Educational program to improve quality of life among elderly regarding oral health. Future Dental Journal. 2018;4(2):211-5.

12. Čanković $\mathrm{S}$, Ač-Nikolić $\mathrm{E}$, Mijatović-Jovanović V, Kvrgić S, Harhaji S, Radić I. Quality of life of elderly people living in a retirement home. Vojnosanitetski pregled. 2016;73(1):42-6.

13. Datta D, Datta PP, Majumdar KK. Association of quality of life of urban elderly with socio-demographic factors. International Journal of Medicine and Public Health. 2015;5(4).

14. Van Nguyen T, Van Nguyen $H$, Nguyen TD, Van Nguyen $T$, Nguyen TT. Difference in quality of life and associated factors among the elderly in rural Vietnam. Journal of Preventive Medicine and Hygiene. 2017;58(1):E63.

15. Akbar S, Tiwari S, Tripathi RK, Kumar A, Pandey NM. Reasons for Living of Elderly to In Old Age Homes: An Exploratory Study. The International Journal of Indian Psychology. 2014;2(1):56-61.

16. Chen H-M, Chen C-M. Factors associated with quality of life among older adults with 
chronic disease in Taiwan. International Journal of Gerontology. 2017;11(1):12-5.

17. Suh S, Choi $\mathrm{H}$, Lee $\mathrm{C}$, Cha $\mathrm{M}$, Jo I. Association between knowledge and attitude about aging and life satisfaction among older Koreans. Asian Nursing Research. 2012;6(3):96-101.

18. Christiane C, Paulo M, Alves AT. Educational level, socioeconomic status and relationship with quality of life in elderly residents of the city of Porto Alegre/RS, Brazil. Brazilian Journal of Pharmaceutical Sciences. 2010;46(4):805-10.

19. Rondón García LM, Ramírez Navarrro JM. The impact of quality of life on the health of older people from a multidimensional perspective. Journal of aging research. 2018;2018.

20. de Paiva FTF, Lima LR, Funez MI, Volpe CRG, Funghetto SS, Stival MM. A influência da dor na qualidade de vida de idosos portadores de Diabetes Mellitus [The influence of pain on elderly diabetics' quality of life][La influencia del dolor en la calidad de vida de ancianos portadores de Diabetes Mellitus]. Revista Enfermagem UERJ. 2019;27:31517. 